\title{
REMIGRATION AND TELLING ABOUT IT: STORIES OF ESTONIANS FROM RUSSIA
}

\author{
Anu Korb
}

\begin{abstract}
I will analyse the stories which focus on the reasons for returning to Estonia and remigration and have been written and told by Estonians who were born in Russia and returned to their motherland. These people returned to Estonia during 1941-1958 until the time Estonia became newly independent. Their ancestors had migrated to the rural areas of Russia since the middle of the 19 th century.

Stories about returning to homeland and adapting to the new environment have for a long time been limited to specific groups of people. They reached wider audiences after Estonia regained its independence and censorship weakened in Russia, and also as a result of the so-called biography boom in Eastern Europe. The context, time and situation of recording a narration or narrative shape the tales and can be repeatedly reassessed in the course of time.

Stories about returning to homeland are both individual and collective; they express the experience of individuals as well as of a community or group. The stories of Estonians from certain regions are rather similar. The time and reasons for returning - forced or voluntary - have also had an impact on the stories. People do not mention shameful events in their lives or describe them only briefly. Even though this return of Estonians is not migration across state borders, most of these stories can still be classified as tales of traditional remigration. These stories give us information about the migration behaviour of remigrated Estonians and the emotions, attitudes and values associated with returning.
\end{abstract}

Key words: Estonians, life history, remigration, Russia, storytelling

\section{INTRODUCTION}

I will analyse the stories of Estonians who were born in Russia and returned to their motherland, which focus on the reasons for returning to Estonia and remigration. I have left out stories about the first major return of Estonians in the years 1920 to 1923, when more than 37,000 Estonians left Soviet Russia to settle in independent Estonia (Valitsusasutiste... 1934: 210); most of the people who returned back then have passed away by now. The Estonians who returned most recently, after the Republic of Estonia became independent again, have also been left out from this review as the topic deserves a separate study. 
Stories about returning to homeland and adapting to the new environment have for a long time been limited to specific groups of people. Estonians living in Russia have generally tried to hide their origin from the public. The same tendency has been noticed by researchers of the life stories and folklore of Ingrian Finns (see, e.g., Reinvelt 2002: 6-7) or in research of the stories told by people who emigrated or sought refuge in the Western world (see, e.g., Kõiva 2003: 67-68, 77). Estonia regaining its independence in 1991 and the weakening censorship in Russia around the time introduced the need to discuss one's ethnic heritage prepared the foundation for the emergence of such stories in Estonia. Many researchers, among them Ene Kõresaar, have referred to the public role of memoirs and biographies during the period when Estonia regained its independence (Kõresaar 2005: 21). Large-scale publication of biographies and memoirs can also be associated with the so-called "biography boom" that has appeared in Eastern Europe in recent decades (Humphrey et al. 2003).

My work is based on 42 long interviews from 2003-2007. The topics of these interviews covered the emigration of their ancestors, life in settlements, remigration and adaptation. The second source was 50 texts submitted to the campaign of collecting life histories Migration and Life in the New Homeland, organised in Estonia in 2004. In these manuscripts people also described their experiences of returning to Estonia and adapting to the local life. Two-thirds of the authors of these life histories were women and one-third were men; the majority were born in some Estonian settlement in Russia between 1923 and 1952.

The interviewees were generally familiar with my work in studying Estonians in Russia. The interviews had been agreed in advance, some interviewees contacted me on their own initiative in order to get if off their chest; I personally recorded the life histories of the returners from Estonian villages in Russia whose education had been cut short by the difficult times and who were thus of poor literacy. The interviews were usually conducted in Estonian at the homes of the interviewees, and were supported with family photos and documents people had kept over the years. As experiences and stories are both individual and social at the same time (Michel 1985: 86) people shared in their written and oral stories, in addition to their own, the experiences of their families and communities.

The written stories certainly differ from those recorded in a spontaneous story-telling atmosphere. Writing down their biographies, people have more time to think about their narrative and polish it. Tiina Kirss, Estonian scholar of life histories has argued that their stories represent a constructed past, which proceeds from the present moment of writing and is recreated on the basis of the memory of the writer and often also of people close to them. The 
aging of communities has motivated the recording of these migration stories while narrating about these is inreasingly abandoned (Kirss 2006: 621-623). The stories that have been told are presented in a situational and cyclical manner, often as stories of personal experience (see Stahl 1989: 29-49) and they can easily be recomposed and adapted to specific audiences.

I realised how superficial the knowledge of Estonians at home was of Estonian settlements in Russia (Korb 2002: 150-151) and felt motivated to improve mutual understanding. The wider background of my study is based on observations and conversations with remigrated Estonians, conducted at their regional gatherings, and meetings of the Association of Estonians in the East, which groups Estonians remigrated from Russia and from other countries east of Estonia. Interviewing the returned Estonians and encouraging them to write down the stories of their families and villages was the logical continuation to the folkloristic fieldwork carried out in Estonian settlements in Russia since 1991.

I was interested in the question which of the events that are associated with remigration are worth remembering and retelling? How are migration narratives created? Can we detect any typical plots in them? Do the stories about "the road to Estonia" belong among family histories, stories of Estonians from certain regions or migration stories in general?

\section{HISTORICAL BACKGROUND}

Mass migration of Estonians to the sparsely populated areas of Russia started in the second half of the 19th century and lasted until the declaration of the independence of the Republic of Estonia in 1918. Even though some Estonians also settled in Russian towns, most of them migrated in search of a land of their own: This shows that people mainly migrated for agrarian and economic purposes (Rosenberg 1998: 55). The policy of the Tsarist Russia was to favour migration in every way. State and crown lands were offered to the migrants either free of charge or for a small price (see Vassar 1975; Maamägi 1980). The emigration took place in three waves:

(1) To the Crimea and Samara in the 1850s and 1860s;

(2) To Caucasus, Russian inland and Siberia in the 1880s and 1890s

(3) Across Lake Peipus and to Siberia at the beginning of the 20th century, mainly during 1907-1910 (Nigol 1918: 10-11, Korb 1996: 240).

Some Estonians lived outside their ethnic settlement area before that time: either as refugees of war or after being sent to exile by the Russian Tsar. The 
first Lutheran colony in Siberia was Ryzhkovo village, founded in about 1803. After laws favouring deportation were adopted in 1820, Estonians settled in that village (Kulu 1997: 85). The Tsar's decree (1845) ordered that all the Lutherans living in West Siberia be gathered to Ryzhkovo and those in East Siberia had to be gathered to the Minussinsk region. When the kernel settlements became overpopulated, the settlers would occupy a wider territory (cf. Viikberg 1988: 284-288). While in 1897 there were 113,813 Estonian-speakers living in the Russian Empire, in 1926 the number of Estonian-speaking inhabitants in the Soviet was already 139,486 (Kulu 1992: 19, 23).

Most settlements were founded according to the ethnic principle and the core of their population consisted of people who had migrated from the same region. At first people built their houses on plots from local materials (see Mainicheva 2002: 156-159).

Peaceful life on their own land that started with so much hope but did not last long for Estonians in Russia. The establishment of the Soviet power in 1940 brought along considerable changes - all religious life was banned, traditional farm life was destroyed and people were forced to work at collective farms. Civil war and extensive repressions ravaged the villages - they were first applied against wealthier people or the so-called kulaks ${ }^{1}$ and then against the minority population. During the Second World War that reached the territory of the USSR in summer 1941 men from villages were mobilised to war.

\section{RETURN MIGRATION AND RETURNED ESTONIANS}

Migration research has generally been the domain of demographers, and social sciences, who often use questionnaires, archive data, and other sources in their work (see, e.g., the study of Finland Swedes in Canada by Mika Roinila (2000), research into remigration of Estonians from Western Siberia by Hill Kulu (1997)).

Analyses of return migration have been legion since the 1960s. In the 1980s, scientific debates among scholars took place on the return phenomenon and its impact on origin countries (Kubat 1984). There exist several definitional approaches to return migration (see Cassarino 2004: 269):

(1) Neoclassical approach - return migration seems to be viewed as an anomaly, if not failure of a migration experience;

(2) New economics of labour migration - return is part and parcel of migration project, as the logical outcome of a "calculated strategy"; it views return as the natural outcome of a successful experience abroad during which migrants met their goals; 
(3) Structural approach argues that return is not solely analysed through the individual experience of the migrant, but it is also a question of context. They argue that the area of settlement determines the reintegration process of returnees and reshapes their expectations.

(4) Transnationalism - return is not necessarily permanent, it takes place when conditions at home are viewed as being favourable enough. Activities are implemented by regular and sustained social contacts over time across national borders (Portes 1999: 219).

(5) Social network theory views returnees as migrants who maintain strong ties with their former places of settlement in other countries. Return migrants are seen as social actors who are involved in a set of relational ramifications. Thanks to the insights of transnationalism and social network theory return is no longer viewed as the end of the migration cycle; it constitutes one stage in the migration process (Cassarino 2004: 268).

Thus, the people who were interviewed and who wrote down their stories have been born in Estonian or Lutheran villages in Russia and returned to their motherland since the annexation of Estonia in 1940.

In the 19th century, migration of Estonians to Russia was not a typical cross-border migration, but was rather inner migration. However, people still travelled thousands of kilometres to settle in places where natural conditions, traditions and customs were completely different and these facts allow to observe the migrations of Estonian in the perspective of these models (see assarino). I agree that remigration does not mean the end of the migration cycle but rather the stage of the migration process, but for my research structural approach, which has been mostly used by anthropologists, sociologists, and others, has been essential. This involves not only the individual experience of a migrant, but also the context (for example, time and space, and the social and institutional factors in host and home countries).

Those who returned can be distinguished in different ways:

(1) Civilians evacuated from regions on the coast of Lake Peipus by the German army in autumn 1943 (Arens 1966: 28).

(2) Communists and Estonians engaged in working-class movement in 19401941; people recruited for party activities in Estonia in 1944-1945.

(3) People demobilised from the Soviet army in 1945-1946 (mainly from the Estonian Rifle Corps).

(4) People who returned after the Second World War voluntarily, to be reunited with families and by invitation of their relatives (Kulu 1997: 132144). 
(5) People who returned to their motherland from 1950 until the Republic of Estonia was re-established.

\section{REMIGRATION STORIES}

Stories about returning to Estonia are also part of the migration history of Estonians. Of course, the life stories of people do not offer us a full reflection of the historical truth, but they are still important sources of information - they also lead us to the thoughts and feelings, attitudes and values of the people who tell them. While studying oral history, one has to take into consideration the time, situation, audience, etc. because these, in turn, shape the stories.

Brigitte Bönisch-Brednich, who has analysed the migration stories of Germans in New Zealand, finds that migration as a turning point in a person's life becomes a personal narrative, but the structure of people's life histories is closely connected to the social and cultural environment that surrounds them (Bönisch-Brednich 2003: 117, 119).

The stories of Estonians who lived in the Russian terrotory on the coast of Lake Peipus focus on the evacuation of the non-Russian population in 1943 when the German army retreated towards the west (Arens 1966: 28). These stories can be classified as escape stories. The same event is remembered and told quite differently. I will give three accounts as examples:

Hitler announced the law that all nations must be taken from Russia back to their own countries. This meant that Estonians had to go to Estonia, Germans to Germany, Poles to Poland, etc. We were told that a horse-drawn sleigh was going to come to the house and we were given 24 hours to pack our things. And we were taken to the train station where a train for Estonians was waiting. We were allowed to take food, clothes, dishes and animals, and we only had a goat at the time. There was a separate carriage for animals and we could go and see to them when the train stopped. This was a great blessing for our mother as she had always wanted to leave Russia and go to live among the Estonians. When the train left the station and headed for Estonia, the women in the carriage played the guitar and sang that whatever coast or country you take us to, never take us back to Russia. [---] EFA, Korb I, 215-216 < Tallinn < Leningrad Oblast, Sokolova V < woman, born in 1935.

[---] The Germans came to take Estonians back to Estonia. Those who could ran away and those who were caught were brought back. Their 
principle was that Estonians had to live in Estonia. This is how my grandmother's sister Miili and her family were brought back. She was given some land here and started inviting us back here as well. [---] EFA, Korb II, $8<$ Tartu < Pskov Oblast, Lomovo V < woman, born in 1932.

In August 1943, my mother found out from the villagers that people were being recruited for work in Estonia. Transport was organised of course by the German army. We did not have a lot of information about Estonia, but the Estonian soldiers who had been to Markusemetsa had told us that the situation and life in Estonia was much better than in Russia. People kept discussing their getting back to Estonia by means of German transport. We had already experienced the barbarity of Germans when they destroyed our village. But we had been left without a roof over our heads for five times and the situation in Kabitsino was getting worse and worse. Getting to Estonia, even by means of the terrifying German transport, was like a hope of escaping the war and the misery of Russian villages. [---] We were added to the list and told that we had to be ready to assemble at first notice. The notice to turn up at Kudiver with all the luggage we could carry came two weeks later. It was the beginning of September, mother packed some underwear and a few pillows in our chest. Boiled cabbage in a glass jar, potatoes, barley bread and some eggs were put in the rucksack. A tin bucket with drinking water went in the handbag. During the day we said goodbye to grandmother. Our uncle took our luggage to Kudiver on his horse-drawn cart. Twenty-odd people had gathered there in a meadow by the edge of the town. Uncle left soon, but we had to spend the night in that meadow. Two tarpaulin-covered lorries with gas generators arrived in the morning. We went to the town of Ostrov ${ }^{3}$. Over there, we were ordered into the town sauna, where our clothes were treated with heat against lice, but we could not wash ourselves as there was no hot water. After that, we were taken to the railway station's warehouse where about fifty people were already waiting. We had to spend another night there. More than a half of the people who had gathered were not Estonians. EFA, Korb IV, 243-244 < Estonia, Valga County, Hummuli V < Pskov Oblast, Markusemetsa V < man, born in 1929.

This shows that people tell the stories of their families against the background of official directives and orders. The first story places the emphasis on being Estonian and one's wishes coming true; the second one is rather laconic and interprets evacuation as injustice; the third one focuses on surviving in difficult circumstances and the hope of escaping a miserable life. 
Preparations for leaving home holds an important place in the stories of people who were evacuated. People express the emotions they experienced when leaving their homes and how their actions were driven by these emotions. They show how things that were essential in their everyday lives were re-evaluated when the turning point arrived and how they lost their former meaning:

[---] We were all told to move out of the rooms, to make them all empty. We had this furniture our father had made and it was all taken out. And I remember how we, the children were never allowed to touch the spinning wheel, because it was a tool and then mother told us in the yard that now you can go and take a ride on it. Then we turned it around, took the wheel off, my little sister sat on it and we rode it around the yard, it was such fun for us.

[---] When we started leaving the village with this horse, my mother looked back towards the village and saw that the Germans had arrived with big carts and were loading the furniture on them. But this was already far away from houses and since we had such really beautiful furniture made of walnut. And my mother ran back and took a stone and broke the mirror with it. [---] ERA, DH 26 (24) < Tartu < Leningrad Oblast, Volosov Region, Lamme $\mathrm{V}<\mathrm{man}$, born in 1930.

People also tell about their journeys and their fears about the quarantine camps:

In the morning, at dawn, people were ordered into the cargo carriages, where straw had been put on the floor. We were off soon, but the carriages stopped at larger stations for hours so that we only got to Klooga station three days later. We were taken to the gate of the prison camp in lorries. This scared people. It appeared that we were not treated as prisoners. They housed us in the stone buildings of the former military camp. The people who had arrived were fed broth in which noodles had been boiled. The same broth with an odd noodle swimming in it was fed to people once a day on all following days as well. Once people had finished the food they had taken with them, the days of starvation arrived. A farmer saved us from starvation by taking potato pickers to his farm. [---] EFA, Korb IV, 244 < Estonia, Valga County, Hummuli V < Pskov Oblast, Novorzhev District < man, born in 1929.

People often describe quarantine and the national cautionary measures applied against the refugees as humiliating (see Kõiva 2003: 64 about Estonian Swedes). However, these stories also speak of surviving in critical conditions and overcoming the circumstances: 
[---] Livestock carriages were standing at the train station. There wasn't enough room in the carriages for the things people had brought with them and some of it was left on the platform. People were agitated and nervous. The Estonian who was organising the departure ordered my mother to help an old lady put her luggage in the carriage. My mother didn't go, because she was putting her own things into the carriage and we, her two children, four and two years old, hung on to her skirts, crying and getting in her way. The official got mad at my mother's refusal and slapped her face. He took my mother's passport, ripped it in two, threw the pieces on the floor, told my mother she was going to the camp with the Russians and went away. Mother picked up the pieces of her passport and when passport control arrived, she apologised for it being broken. She told the control that her little children had ripped it. EFA, Korb III, 182 < Tartu < Leningrad Oblast, Volosov District, Zarechk V < woman, born in 1941 .

The stories of Estonians living on the Russian territory on the coast of Lake Peipus are very similar to the stories of people who fled to the Western world (see, e.g., Kirss 2006). Both were instances of forced migration and that caused similar stories. The life stories of Ingrian Finns, living close to the Estonians and shared a common fate (see, e.g., Reinvelt 2002), are also similar. The collective experience of the people told in their stories is important (KaivolaBregenhøj 1999: 59). Foodis central in the stories told by people who lived near St Petersburg, known as Leningrad at the time: they give detailed descriptions of the food they took with them, speak about the meagre food offered on the road or in the quarantine camp, etc. These stories may be influenced by the widely-discussed Leningrad Blockade, but it is likely that the villages also suffered from lack of food. Therefore, people may have seen evacuation to Estonia as the opportunity to escape the worst:

The "Great Patriotic War"4 was raging on. Estonia and also a part of Russia - at least Leningrad Oblast - had been occupied by the Germans. My mother was in a tough situation - there was no work, but she had five children to feed. The youngest one, a son, was born on 28 December 1941. My mother knitted socks and mittens for the Germans and got food in return. Sometimes the Germans themselves gave candy to the children. [---] Many Estonians started returning to Estonia because of hunger. They also advised my mother to go to Estonia - she would not have to face hunger over there. So mother went to the German commandant's office to apply for a permit to return to Estonia. People there counted her children - ein, zwei, drei - and wondered how on earth she intended to 
get there? Mother stuck with her request. She was given some flour and milk to take with her. Two sledges had also been prepared. And so mother set off with her five children - the youngest of them (a son) was 1 month and 20 days old - and headed towards Estonia on these sledges in February 1942. The eldest daughter Siina was 10 back then, Roosi was 8, Niina was 5 and Ludmilla 3. [---] Mother was in the front with one sledge (and the baby was on the sledge), Siina and Roosi pulled the other sledge. Ludmilla was sitting on it and Niina was walking behind it. Of course we had to find somewhere to stay for the night, get some more food, etc. [---] When we got to the Estonian border in Narva, we took the train to Paldiski. People were sent to different places all over Estonia from there. My mother and her children ended up in Viljandi County. EFA, Korb III, 6 < Tartu < Leningrad Oblast, Gatchin District < woman, born in 1939 .

People who arrived in Estonia immediately after the war and later do not mention food separately in their descriptions of preparing for the journey. They mainly focus on the complications connected with leaving the village - people living in Russian villages did not have passports and they did everything to stop labour leaving the villages. This meant that people had to resort to any means they could think of: bribing their bosses, using their acquaintances, etc.

[---] We came in December. Forty-seven. We arrived right on Christmas Eve. My journey was very long as the trains did not run that often. People from here wrote to us saying do not drive through Kirov. ${ }^{5}$ They said we should come through Vologda. ${ }^{6}$

A.K.: Who did you have here in Estonia, who wrote to you?

Well, two of my uncles got here with the front during the war and the third one was a stepchild in my uncle's family, he now lives in Elva. ${ }^{7}$ And my uncle took his family here a year before, in 46, I mean his father and mother as he had no other family at the time, he brought them to Estonia and, well, and my grandmother used to write.

A.K.: Was it easy to get permission to leave?

Oh no, we had a lot of trouble with leaving. We had to keep making hooch to be able to leave, something like...

A.K.: Who did you have to give it to?

The chairman of the collective farm, we had to give it to him, or he would not give us the certificate allowing us to leave. No one over there had a passport. [---] ERA, MD 403 (31) < Estonia, Võru County < Kirov Oblast, Oparino District < woman, born in 1933. 
The life history below describes informal documents and procuring these with the help of relatives and connections. Regardless of the existence of certain documents, refugees were ppersecuted and searched after in collective farms in Russia. Those who were caught wree punished as criminals. The often long journey to Estonia was like an adventure, where bribery and illegal deals served as a pass to the train.

[---]We had this damned Traansberg, this chairman of the Village Soviet, and he was a damned, well, he did not like it at all when people were leaving. So we got to Asino ${ }^{8}$ and unloaded all our things, settled everything with the boys and so we were there. Father was taken back to Asino the next day. I cannot remember whether he went to the market or just out or where he went. Maybe he went to get the tickets. And he was apprehended and there were no telephones or anything, so we did not know anything. But that landlady told us that she had seen him taken away. And two men came there the day after. The landlady with whom we were staying lifted the cellar door and told us to go down there. We went to the cellar where potatoes were kept and stayed there. The men asked whether we were there. She told them that we had left the day before.[---]

A.K.: Did you have any documents at all?

No, we had certificates from the Village Soviet. ${ }^{9}$

A.K.: So the Village Soviet allowed you to leave after all?

We had, well, how do you say it, stepmother or my sister's husband's stepmother, she was the chair of the Village Soviet. So that's how. But there was nothing official. They put the names down and stamped it and so and so. It was just an identity document. That I am this person. But there was no photo or anything. But I guess no photos were put in passports at that time, there was no passport system. [---] My aunt's husband, he was already trying to find train carriages. Livestock carriages were used to transport people. And this Eduard said that we were promised a carriage for tomorrow. I cannot remember what he had, a quarter of a pig or half a pig or something, this had to be given away for it. And then we went to that carriage, but the carriage was not full. This was a sad thing. Half the carriage was full and there was no heating. But there was this little oven; the chimney had been built through the roof. But the other end remained empty then and some damned young thieves came there. [---] When a station was approaching, they all went to the door, jumped out, two or three of them remained standing on the door and right before the train left they pulled bags from old people's hands and threw them 
onto the train and the others caught them. That's what they did. And they shook their fists at us. Keep quiet! They put their fingers on their mouths and, you all be quiet. [---] ERA, MD 401 (25) < Tallinn < Siberia, Tomsk Oblast, Liliengof $\mathrm{V}<$ man, born in 1929.

In 1955, the deportees were allowed to send children alone on a special train to live with their relatives in Estonia alone. This train brought to Estonia underage children and youth of differrent age. Parents were allowed to follow their children about a year later. Sometimes, however, parents left first and the rest of the family could follow, circumstances permitting. In the next example, the woman who travelled from Siberia to Estonia on her own as a teenage girl mainly remembers the difficulty of the journey and the things she had to survive when travelling - it was the first time ever that she had travelled so far:

[---] I travelled from Siberia to Estonia on my own when I was thirteen. I hadn't even seen a bus back then and, and, and [laughs] I had to get to change trains in Moscow and then that one says, my sister then told the carriage guard and paid and told to send me to another station, but that one was as stupid as me, that these stations there are next to each other Leningrad and that Yaroslavl and and they put me on the bus and I guess sent me to Riga, Rizhsky vakzal. ${ }^{10}$

A.K.: That was around nineteen fifty?

Yes, yes, yes. Yes and I remember there was this strong man standing next to me all tied up and says, Ya tebya dovezu. ${ }^{11} \mathrm{He}$ stood there and when we were left so, there was of course a lot of people and we were standing next to each other, and he asks me, do you have lots of money? And I, well, I had 100 roubles, but I told him I only had 10 roubles. And he then told me, no tagda mne staboi delat netshevo. ${ }^{12}$ And then, I can't really remember, I guess I asked someone where I had to get off. Anyway, I did get to the right station in the end.

[---] You see, I had to travel here, you know, to Meeri orphanage. ${ }^{13}$ Near Nõo. My mother lived there. My sister and mother lived there, my sister's husband was a director there at the time. The train came from Moscow through Tartu ${ }^{14}$. I should have got off the train in Tartu, but I went on to Tallinn. And there was a train that went from there to Tartu. I should have then travelled from Tartu to Nõo ${ }^{15}$ and then go by foot from there. Nobody had told them, my sister had not sent them a telegram to let them know I was travelling. I travelled to Elva. People in Elva told me, oh, its nine kilometres from here to Nõo and I got to Nõo in the evening. Then I spent the night on the bench at the station, like a little beggar. 
Meeri orphanage is a manor and has a large park and a big beautiful gate. And for me, I had just come from Siberia, it was like a fairy tale and I get to the gates and I went in and I saw them run out from the manor. One in front, my sister, she is a very tall girl, and then someone behind her. And I immediately thought they were my sister and my mother. And they're running. And then after I saw them, I started crying. [---]

People who came later with their families often describe the emotions they felt when leaving their homes, which are somewhat similar to those described in the stories told by people who left as refugees:

The most difficult thing was selling the house, selling our home. This was the hardest thing. We sold to Karla's cousin. Not because it was hard to sell, there were enough buyers, but it was just so difficult for us, like where do you go once you've sold your home, where do you go, under the trees in the forest. We were afraid of what was ahead of us, we didn't know. But we so wanted to come and we had been here before on visits. [---] ERA, MD 257 (43) < Harju County, Keila < Siberia, Kemerovo Oblast, Koltsovo V < woman, born in 1929.

Stories of people who came to Estonia voluntarily often focus on some conflict they had experienced in Russia which made them decide to leave the village. Such conflicts may have been associated with family problems (e.g., bad relationship with one's stepfather) or conflicts at the working place.

The extremely hard work on collective farms in the home villages in Russia and the autocracy of local officials are also mentioned in many stories:

When I think about it now, then, oh my God, Heaven help us. It is terrible under which conditions we had to work there. I cannot even imagine it any more. [---] ERA, MD 242 (3) < Harju County, Loo < Siberia, Krasnoyarsk Krai, Upper-Suetuk V < woman, born in 1936.

After the harsh experience with imprisonment and deportations, the threat of imprisonment nad punishment was taken very seriously. This becomes evident in a daughter's narrative about the fate of her mother and herself.

My mother had to leave because, my mother was left alone and then they had to do this hard work, carry these sacks of grains and everything and my mother hurt herself, she had these terrible pains inside, she was hospitalised for a month. And she was, you know, I see it like a picture, like those who had been let out of the Osventsium camp. ${ }^{16}$ But no documents were given, once you came home you were sent to work again. [---] You know, Ella, leave this village if you can, because they are already prepar- 
ing documents about you and they will send you to prison. Because you cannot go to work or you cannot work. And then my mother, we had a calf at the time, I guess she killed it and managed to sell it. There was only enough money for two, my brother was five years older than me and he already spoke Russian. ERA, DH (87) < Tartu County, Elva < Siberia, Kemerovo Oblast, Yuryevka V < woman, born in 1937.

Some Estonians decided to return to Estonia because they wanted to remain Estonians. They were afraid that their children would become Russified when living in Russia and they saw returning to their motherland as the only way to avoid this. Unfortunately, many of those who returned had to face disappointment:

We thought that they come here, marry Estonian women and all, but it didn't go like this. They still married Russian women. [---] See, this Russian spirit was in them and, and they married Russian women. ERA, MD 257 (43) < Tartu County, Elva < Siberia, Kemerovo Oblast, Koltsovo V < woman, born in 1929 .

Many researchers have claimed that the wish to return to one's ethnic homeland is characteristic of diaspora communities and many countries have tried to alleviate their lack of labour by favouring remigration on the level of state, for example Germany after the Second World War; Japan in the 1980s (Tsuda 2001: 60-61). Returning from Siberia to Estonia was of course somewhat easier - they were not different countries at the time. However, the wish to stop the inflow of mainly Russian migrants even a little can be seen behind the campaign of calling Estonians back to Estonia, which was carried out in Estonia in the 1960s and 1970s:

[---] In 67, they came to Upper-Suetuk with that Estonian campaign, asking Estonians to return home.

A.K.: Wait, who were the people leading this campaign?

I have to now... Leontina knows that and Aleks, they know it better, they came. [---] Somewhere around Kanama ${ }^{17}$ they all came there at first and then started going elsewhere from here.

A.K.: Was it done on the government level or where they some private people or-?

It was, it was bigger, it was the government, I think it was on government level. I, I don't know exactly, I could be telling it all wrong now. But they were given flats here at first and, and they more or less got to the barns, let's say that women started milking cows and, and men were working in 
fields or, or doing technical stuff, and. But this, this project sort of failed somewhat. People still went elsewhere... [---] ERA, MD 245 (9) < Harju County, Laagri < Siberia, Krasnoyarsk Krai, Upper-Suetuk V < woman, born in 1952.

It seems that recruiting people with such campaigns was rarely successful in the former Soviet Union. The chairmen of some Siberian collective farms also tried to avoid lack of labour by bringing in numerous people of other nationalities. For example, Chuvash people were lured to the Estonian village of Kaseküla (Berezovka) in Tomsk Oblast, they were given new semidetached houses, their utilities were paid, etc. Unfortunately, the fortune seekers left as soon as the bonuses were cut off.

Many who returned from Russia describe Estonia as the land of their dreams that they had heard a lot about as children:

I think it was in '66 that I came to the Viljandi Culture School and I graduated in '70. I was mainly with my grandmother. I may be the one in my family who spent the most time with her, I was the first child in the family. [---] And in my childhood, I had heard so much about Viljandi and Estonia, and also my grandmother that I still remember many surnames I was told in my childhood. ERA, MD 248 (1) < Põlva County, Tilsi < Siberia, Kemerovo Oblast, Yuryevka V < woman, born in 1949.

Brigitte Bönisch-Brednich describes the decision of a new settler to stay in the new country through taste: A country that offers me something as tasty as this must be good for me (Bönisch-Brednich 2003: 121). A similar attitude can be observed in the stories of people who returned to Estonia later, where visiting acquaintances in Estonia or arriving in Estonia is associated with some pleasant taste.

A.K.: Did you visit Estonia before you came back here?

We did once. My brother-in-law and his wife did and then we did as well. But what year was it... I'll tell you in a minute. I had children and they were small. Well, Jaan is now forty-six. He was six or seven then. Forty years ago. The Paju ones were alive. That same Paju Liine was alive. What village was it where we stayed with them...? [---] Well, what I remembered the most was chocolate butter. I have thought back many times how I kept buying it, that chocolate butter. And when we came here to Estonia, when we moved here for good, we stayed with my brother and there was smoked Baltic herring. We didn't have it over there. God, I had so many of them that I have never ever bought any again. Then I liked 
them, we ate them every day. They tasted so good. [---] ERA, MD 243 (16) $<$ Harju County, Keila < Siberia, Krasnoyarsk Krai, Upper-Suetuk V < woman, born in 1936 .

[---] My granny then, in the morning when I woke up, it was the time of year when apples were ready and when I woke up in the morning, she had put a beautiful apple on the table and I, well, in Siberia we did not have these apples. [---] ERA, DH 30 (68) < Tartu County, Elva < Siberia, Kemerovo Oblast, Yuryevka V < woman, born in 1937.

Stories of pleasant tastes are interwoven with stories of goods in short supply. These stories have a strong material side and Estonia is seen as a country rich in goods and full of opportunities:

[---] My mother had a friend who used to live and still lives here. And this friend came to visit us in the village and brought us lovely clothes, plaited skirts and all, they were very fashionable back then. And I always said then: when I grow up, I will move away to Estonia. And, and this is how it went. [---] ERA, MD 244 (1) < Harju County, Loo < Siberia, Krasnoyarsk Krai, Upper-Suetuk V < woman, born in 1948.

These stories can be compared with the stories Estonians in homeland tell of their experience with goods in short supply (cf. Kõresaar 2003: 150-178).

People who came to Estonia, middle-aged or at older age often emphasise that they came to Estonia with considerable material possessions - these stories support the self-appreciation of people and the image of Estonians as industrious people.

What, we came with our own stuff! We had eleven tons of stuff with us. We brought everything, even the poke.

A.K.: So you brought all your things from Siberia?

Well, not everything, we left some sofas and beds and, we left those things there and... But all the wardrobe and... and even grains! See how stupid we were, we brought thirty sacks of wheat.

A.K.: But how was it possible to bring all this stuff? In train carriages, or-?

With three lorries, they brought it all to Asino with three lorries, it was fifty kilometres to there. With three lorries. And then took the carriages and loaded them up and... They were called container carriages. Yes, container carriages, there were two... three container carriages, two three- 
ton ones and a five-ton one. And they were already loading the stuff into the carriages before we started coming. So we got... We had been here a week or maybe even less, when we were already told that our stuff had arrived. [---] In Kohtla-Järve, ${ }^{18}$ then lorries from the collective farm were sent there and... ERA, MD 232 (2) < Põlva County, Räpina < Siberia, Tomsk Oblast, Berezovka V < woman, born in 1923.

Other important reasons behind the decision to come to Estonia were acceptance of the decision made by one's next of kin, surrendering to their wishes, or one's own desire to live near them:

[---] My parents left in '76, yes.

A.K.: Why did they leave?

I guess they were just asked so many times to come back, because my sister left, or my middle sister in '75, when I went. I was already married then and I had a child and, well, we went there on holiday and my sister was graduating from secondary school and, and we just talked like this, we talked so much that my sister left and after that, when my sister was here, she was already studying at the pedagogical institute here, then I talked to my sister and we decided to talk our father into it, that they have to come as well. ERA, MD 245 (8) < Harju County, Laagri < Krasnoyarsk Krai, Upper-Suetuk V < woman, born in 1952.

[---] Did I ever think I was going to come and live here? No, I never even thought about that.

A.K.: But your children kept inviting you?

Yes. My children kept inviting me, saying I shouldn't be there on my own. Could not, could not keep a cow any more. You could somehow buy or get some hay, but there was no one to look after the cattle. [---] ERA, MD 246 (39) < Harju County, Rapla < Krasnoyarsk Krai, Upper-Suetuk V < woman, born in 1917.

The stories of people who were recruited to work in Estonia by Soviet authorities or who arrived here as members of the Estonian Rifle Corps are clearly distinctive from the other stories about returning to Estonia. It is significant that most of the people who were recruited still prefer not to speak about it or answer the question How did you come to Estonia? with a laconic I had to do what I was told. It is not surprising that people prefer not to remember this event in their lives, especially after Estonia regained independence. 
Stories of recruitment as Soviet authorities are mainly told by those who managed to evade recruitment. A man who later returned to Estonia on his own, said:

[---] One day I was called to the headquarters of the military unit and told that I was going to be demobilised according to the directive of the Minister of Defence of the USSR. I was also told that Soviet Estonia was in desperate need of workforce as the people's economy had to be restored. They suggested that I stay in Estonia and re-qualify in a new specialty. Since I was a man toughened in battle, fluent in Estonian and Russian, had suitable education, then my first job would have been working as a translator at the National Security of Soviet Estonia. [---] My bosses obviously didn't know that I was the son of a so-called "enemy of the people"19 that the NKVD [People's Comissariat of Internal Affairs] had repressed and killed half of my family in addition to my father. [---] There was no way I could work for murderers and frauds and taint the memory of the people I loved. I told them I preferred to go back to my home village in Siberia and carry on working on my specialty. [---] ERA, MD 234 (19) < Otepää < Novosibirsk Oblast, Estono-Semenovka V < man, born in 1921.

The relatives and acquaintances of the recruited sometimes also tell stories of recruitment, often adding their own critical opinions:

Well, her husband was a party member, hence the appointments. At first the headmaster of Rannu School, then Meeri School, then sent here to Elva and this is how it went, he never had to make any decisions himself. [---] I asked why your Peeter accepted such jobs? What do you think? He had not only studied at the pedagogical school in Mariinsk ${ }^{20}$ - it's not even a technical school! Say, he only had secondary education. And he was appointed director, the director of the orphanage. [---] I said, do you really think there were no educated people? Why did you have to agree? Why? [---] My brother also received an offer, he had been to school for four years and he was asked to be the director somewhere. He said, "For heaven's sake", I immediately told them I was no director. And he is not in the party, just a Russian Estonian. They were like putting people in positions. [---] What did they know, they were the children of these ancestors who came, they had never even seen Estonia and they had no idea what life was like here. ERA, DH 30 (69) < Tartu County, Elva < Kirov Oblast, Oparino Region < woman, born in 1937.

The woman who told this story had experienced the negative attitude from the part of Estonians in homeland towards herself because she was born in Russia and wondered what the reasons for such an attitude were. 
The stories of Russian Estonians demobilised from the Soviet army, who launched the second wave of returns to Estonia (Kulu 1997: 141-144), about staying in Estonia and inviting their families to join them, are also rather laconic:

[---] Those who were in the army here, yes, and those who were in the war, they didn't go back, they stayed in Estonia.

- They came after their families.

- They came after their families and, brought them back...

A.K.: So you had many people from the same area here in Estonia, or? Yes! We did. My sister was, my elder sister, she was here. A soldier came for her and, and brought her here, but that soldier was a Siberian boy. [---] ERA, MD 258 (1) < Tartu < Kemerovo Oblast, Kolcovo V < woman, born in 1929 and man, born in 1928 .

The decision of Russian-Estonian men from the Rifle Corps to stay in Estonia is based on the realisation that life in war-torn Estonia was still better than in their home villages in Russia. Most families had also suffered repressions (see, e.g., Kulu 1997: 173). However, they had also experienced the dubious attitude of Estonians in homeland. Russian Estonians were called the oblast men in the Rifle Corps and they had often been considered the same as Russians, but only a few of them let this negative experience affect their decision to return. Below, returning to Estonia is described not by the returnees:

My husband just didn't want to come to Estonia. He was fighting here during the war and he saw how Estonians hated these Russian soldiers. And he just did not want to come. When we came, he came as well, we came in a compartment carriage and he came in a carriage with seats. He was in a different carriage! [---] ERA, MD 232 (2) < Räpina < Tomsk Oblast, Berezovka $\mathrm{V}<$ woman, born in 1923.

This is a revealing account of an Estonian-born in Russia who identifies himself as a Russian soldier and comes to Estonia under his family's pressure.

Similarly to Estonians who fled to the Western world, there were those Russian Estonians whose fate was determined by the year they were born (cf. the story of Eino Viire in Kirss 2006: 66-88). For example, a man sent to war from an Estonian village in Siberia when he was 17 became a professional soldier because of the circumstances:

Since we were living in Estonia at the time, they took us for the Estonian army, I mean the Estonian Rifle Corps already existed in the Urals. And 
so we were taken, 8 or 9 young men altogether, we were taken and to the Urals.

A.K.: So they were all taken from your village?

Yes, they were all from my village, my age and they took us to the reserve regiment of that Rifle Corps. But there, they didn't take you like that, like sending you straight to the front. The Estonian Rifle Corps was still kept sort of, like the Russians didn't trust us. They weren't allowed to the front at first. But I was taken to the unit where we had to train those young commanders. [---] They took us in 45, I got wounded in Kurzeme, came back from Riga to the front again, to the Kurzeme front. But the war was already about to end. But there, on the 5th of May, four days before the official end of the war, lined up and told that I had to go and learn. The Republic of Estonia needs staff and you will go and learn. [---] So this is how it happened with me, with the studies in the military school and then I became a soldier for life. At the start, some older men, they were like, wait a minute, the war is over, I can go home now and how can I go and learn now. Well, I had no way out, I had no profession and I stayed. But why they left me in the military school, this is a big question, because I was the son of an enemy of the people.

Where, how can I go now? But the story is, we ended up in a school, which was taken to Vilnius in the end. It was that old-old school from the time of the Tsar, the one that Laidoner ${ }^{21}$ graduated from. So I went to the same school as Laidoner. [Laughs] Yes, same as General Laidoner, yes. But the principal of that school was Oolef, an Estonian name. And it came out that he was related to Estonians, some generations ago. And those KGB men started, when they saw my documents there, they jumped at me, that how can you become an officer, you're the son of an enemy of the people. But the general said, I'll take the responsibility, I will not give any Estonians to you. And this is how I could graduate and then my salary went up after this and I could, I mean I brought my mother from Siberia to Tallinn. ERA, DH 31 (14) < Tallinn < Siberia, Altai Krai, Estonia $\mathrm{V}<\operatorname{man}$, born in 1926.

It is noteworthy in this story how the man, knowing that Estonians in homeland did not respect people working in the Soviet army, mentions his youth to justify his step and glorifies his choice to become a soldier by going to the same school as General Laidoner. This shows that individuals use certain cultural resources to give meaning to their experience and to tie it with the system of more general social values (Kõresaar 2005: 11). 
The authors of the stories discussed in the article were born in Estonian/Lutheran villages in Russia and returned to Estonia during the period when Estonia was an occupied country, a part of the Soviet Union. Stories about returning to Estonia offer an opportunity to study our migration history.

The key points worth remembering and narrating about are the decision to come back, preparing for the journey and the journey itself. The life stories of people do not give a full reflection of the historical truth, but they allow us to learn about the thoughts and feelings, attitudes and values of people. The stories change in time according to the re-evaluation of people's moral values, the changes in the socio-political situation, etc. and can be reshaped in order to be acceptable for the taste of the narrator/informant as well as the audience/ readers.

Stories about returning to homeland and adapting to the new environment have for a long time been limited to specific groups of people. It might be even said that they have had a therapeutic function. These stories reached wider audiences after Estonia regained independence and censorship weakened in Russia, and as a result of the so-called "biography boom" in Eastern Europe. People still do not want to talk about things that were considered shameful or that might compromise someone.

Stories about returning are both individual and collective; they express the experience of individuals as well as a community. The specific places where people lived in Russia, and also the time and reasons for return - both influenced and voluntary return - have an impact on the stories and often outline the story. The stories become deeply individual when they proceed from specific persons. The same event may be perceived differently depending on one's age, but also on individual idiosyncrasies and personality.

Remigration in Russia was inner migration but in the Soviet period the migration crossed the republic borders and thus still fits in with traditional tales of remigration.

Narratives based on conflict centre on departure from Russia, complications endured during the journey, persecution, and bribing to procure means of transport. Repatriates generally describe differences in their former Siberian home and the historical homeland. The life histories reveal how RussianEstonians perceived prewar and postwar migration as guided by the authorities, how they suffered from ethnic discrimination when occupational forces arrived, and ungrounded promotions to higher positions without adequate skills or education. 


\section{COMMENTS}

${ }^{1}$ Kulak - a category of rich peasants in later Russian Empire, Soviet Russia and early Soviet Union. The word "kulak" originally referred to independent farmers in Russia who owned larger farms and used hired labour.

${ }^{2}$ Markusemetsa - a village in Pskov Oblast, Russia.

${ }^{3}$ Ostrov - a town in Pskov Oblast, Russia.

4 The Great Patriotic War - a synonym for the Second World War in the Soviet press.

5 Kirov - a city in Russia, former Vyatka, situated on the Vyatka River.

${ }^{6}$ Vologda - a city and administrative centre of Vologda Oblast, northwestern Russia.

7 Elva - a small town near Tartu in South Estonia.

${ }^{8}$ Asino - town in Tomsk Oblast, Siberia, situated on the river Chulym.

9 A council and a political unit.

${ }^{10}$ Riga Railway Station.

${ }^{11}$ Russian: "I will take you there."

${ }^{12}$ Russian: "In that case there's nothing to do with you."

${ }^{13}$ An orphanage near Tartu, Estonia.

${ }^{14}$ Tartu - a town in Estonia.

${ }^{15}$ Nõo - a rural municipality in Tartu County, Estonia.

${ }^{16}$ Oswiecim - Auschwitz.

${ }^{17}$ Kanama - a village in Harju County, North Estonia.

${ }^{18}$ Kohtla-Järve - a town in North Estonia.

${ }^{19}$ Enemy of the people - a name designating deportees, kulaks and political opportunists in the Soviet media and political jargon.

${ }^{20}$ Mariinsk - a town in Kemerovo Oblast, West Siberia.

21 Johan Laidoner born in Viiratsi Parish, Viljandi County, Estonia on February 12, 1884. Died in the Vladimir Prison Camp, Russia on March 13, 1953. Was one of the seminal figures of Estonian history between the world wars. His highest position was Commander-in-Chief of the Estonian Army in 1918-1920, 1924-1925, 19341940. 


\section{ARCHIVE SOURCES}

EFA, Korb - biographic manuscripts

ERA, MD - sound recordings on minidiscs

ERA, DH - digital sound recordings

\section{REFERENCES}

Arens, Ilmar 1966. Eine estnische Umsiedlung im Jahre 1943. Baltische Hefte, Vol. 12 , pp. 28-32.

Bönisch-Brednich, Brigitte 2003. Migratsioon ja jutustamine. [Migration and Narration.] Mäetagused, Vol. 23, pp. 114-129.

Cassarino, Jean-Pierre 2004. Theorising Return Migration: the Conceptual Approach to Return Migrants Revisited. UNESCO, IJMS: International Journal on Multicultural Societies, Vol. 6, pp. 253-279.

Humphrey, Robin; Miller, Robert \& Zdravomyslova, Elena 2003. Introduction: Biographical Research and Historical Watersheds. In: R. Humphrey, R. Miller, E. Zdravomyslova (eds.). Biographical Research in Eastern Europe. Altered Lives and Broken Biographies. Aldershot, Burlington: Ashgate, pp. 1-24.

Kaivola-Bregenhøj, Anniki 1999. Life as narrative. Ingrian-Finns tell about their vicissitudes. Ingrians and Neighbours. Focus on the Eastern Baltic Sea Region. Studia Fennica Ethnologica, Vol. 5, pp. 48-60.

Kirss, Tiina 2006. Rändlindude pesad. Eestlaste elulood võorsil. [The nests of wandling birds: Life histories of Estonians abroad.] Tartu: Estonian Literary Museum, Estonian Studies Program at the University of Toronto.

Korb, Anu 2002. Eestlastest Vene Föderatsioonis 1990. aastail. Krimmi kogumik. [Estonians in Russian Federation in the 1990s. The Crimean collection.] Conference proceedings "140 years of Estonians in the Crimea" (9-10 Sept 2001). Tallinn, pp. $150-164$.

Korb, Anu 1996. Ei oska rääkimise moodi kõnelda. Eesti asundused II. [Cannot talk as they speak. Estonian settlements, Vol. 2.] Tartu: Estonian Literary Museum.

Kubat, Daniel (ed.) 1984. The Politics of Return. International Return Migration in Europe (Proceedings of the First European Conference on International Return Migration, Rome, 11-14 November 1981). New York: Center for Migration Studies.

Kulu, Hill 1997. Eestlaste tagasiränne 1940-1989 Lääne-Siberist pärit eestlaste näitel. [Remigration of Estonians in 1940-1989 on the example of Estonians in Western Siberia.] Tartu: Tartu Ülikooli Kirjastus.

Kulu, Hill 1992. Eestlased maailmas. Ülevaade arvukusest ja paiknemisest. [Estonians in the world. Overview of population statistics and distribution.] Tartu: University of Tartu.

Kõiva, Mare 2003. Lugu suurest lumesajust. Rootsieestlaste lood nõukogude Eestist. [The case of the big snowstorm. The spreading of personal experience stories about Soviet Estonia among Estonians in Sweden.] Mäetagused, Vol. 23, pp. 56-94. 
Kõresaar, Ene 2005. Elu ideoloogiad. Kollektiivne mälu ja autobiograafiline minevikutõlgendus eestlaste elulugudes. [Ideologies of life. Collective memory and autobiographical interpretation of the past in Estonian life histories.] Tartu: Eesti Rahva Muuseumi Sari, Vol. 6.

Kõresaar, Ene 2003. Hea elu normatiivsus. Nõukogudeaegse defitsiidikogemuse kujutamisest elulugudes. [Norms of a good life. Representation of goods in short supply during the Soviet time in life histories.] Mälu kui kultuuritegur: etnoloogilisi perspektiive. Studia ethnologica Tartuensia Vol. 4. Tartu: University of Tartu, pp. 150-178.

Maamägi, Viktor 1980. Uut elu ehitamas. Eesti vähemusrahvus NSV Liidus (19171940). [Building a new life. Estonian minority in the Soviet Union (1917-1940).] Tallinn: Eesti Raamat.

Mainicheva, Anna 2002. Bytovaia kul'tura estoncev Sibiri. (Konets 10 - pervaia tret' 20go veka). Diaspory, nezavisimyi nauchnyi zhurnal, No. 3, pp. 153-164.

Michel, Gabriele 1985. Biographisches Erzählen - zwischen individuellem Erlebnis und kollektiver Geschichtstradition. Reihe Germanistische Linguistik 62. Tübingen: Max Niemeyer Verlag.

Nigol, August 1918. Eesti asundused ja asupaigad Venemaal. [Estonian settlements in Russia.] Tartu.

Portes, Alejandro; Guarnizo, Luis E. \& Landolt, Patricia 1999. The study of transnationalism: pitfalls and promise of an emergent research field. Ethnic and Racial Studies, Vol. 22, No. 2, pp. 217-237.

Reinvelt, Riina 2002. Ingeri elud ja lood. Kultuurianalüütiline eluloouurimus. [Ingrian lives and tales. A culture analytical biographical research.] Studia Ethnologica Tartuensia 5. Tartu.

Roinila, Mika 2000. Finland-Swedes in Canada. Migration, settlement and ethnic relations. Migration Studies, Vol. 14. Turku: Institute of Migration.

Rosenberg, Tiit 1998. Eestlaste väljaränne 19. sajandil - 20. sajandi algul: taust ja võrdlusjooni naabritega. [Estonian migration in the 19th century and at the beginning of the 20th century: Context and parallels with neighbours.] Eesti kultuur võorrsil. Loode-Venemaa ja Siberi asundused. Tartu: Estonian Literary Museum, pp. 34-59.

Stahl, Sandra K. D. 1989. Interpreting Personal Narrative text. In: S. K. D. Stahl (ed.) Literacy, Folkloristics and Personal Narrative Text. Bloomington \& Indiana: Indiana University Press, pp. 29-49.

Tsuda, Takeyuki (Gaku) 2001. From Ethnic Affinity to Alienation in the Global Ecumene: The Encounter between the Japanese and Japanese-Brazilian Return Migrants. Diaspora, Vol. 10, No.1, pp. 53-91.

Valitsusasutiste tegevus 1918-1934. 1934. [The activities of governing institutions in 1918-1934.] Tallinn: Riigikantselei.

Vassar, Artur 1975. Uut maad otsimas. Agraarne ümberasumisliikumine Eestis kuni 1863. aastani. [In search of a new land. Agrarian remigration movement in Estonia before 1863.] Tallinn.

Viikberg, Jüri 1988. Vanematest Eesti asundustest Siberis. [On earlier Estonian settlements in Siberia.] Keel ja Kirjandus, Vol. 5, pp. 284-288. 